\title{
Seasonal Microbial and Environmental Parameters at Crocker Reef, Florida Keys, 2014-2015
}

By Christina A. Kellogg, Kimberly K. Yates, Stephanie N. Lawler, Christopher S. Moore, and Nathan A. Smiley

Open-File Report 2015-1203

U.S. Department of the Interior

U.S. Geological Survey 


\section{U.S. Department of the Interior \\ SALLY JEWELL, Secretary}

\section{U.S. Geological Survey \\ Suzette M. Kimball, Acting Director}

U.S. Geological Survey, Reston, Virginia: 2015

For more information on the USGS—-the Federal source for science about the Earth, its natural and living resources, natural hazards, and the environment-visit http://www.usgs.gov or call 1-888-ASK-USGS.

For an overview of USGS information products, including maps, imagery, and publications, visit http://www.usgs.gov/pubprod.

Any use of trade, firm, or product names is for descriptive purposes only and does not imply endorsement by the U.S. Government.

Although this information product, for the most part, is in the public domain, it also may contain copyrighted materials as noted in the text. Permission to reproduce copyrighted items must be secured from the copyright owner.

Suggested citation:

Kellogg, C.A., Yates, K.K., Lawler, S.N., Moore, C.S., and Smiley, N.A., 2015, Seasonal microbial and environmental parameters at Crocker Reef, Florida Keys, 2014-2015: U.S. Geological Survey Open-File Report 2015-1203, 12 p., http://dx.doi.org/10.3133/ofr20151203.

ISSN 2331-1258 (online) 


\section{Contents}

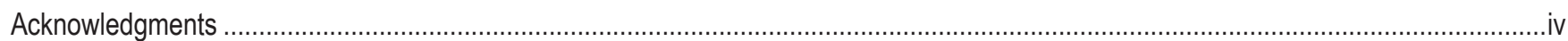

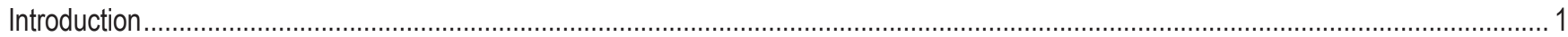

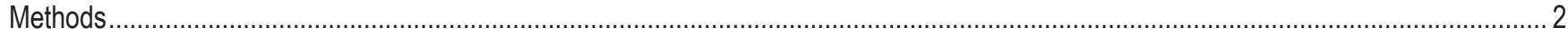

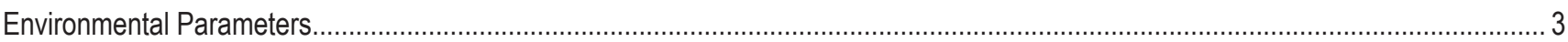

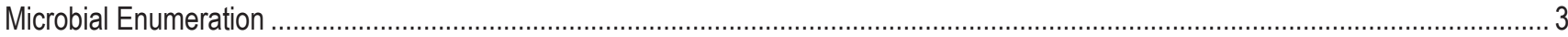

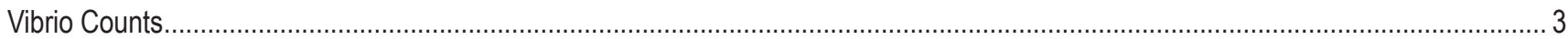

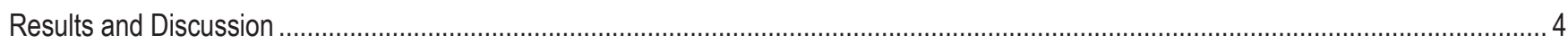

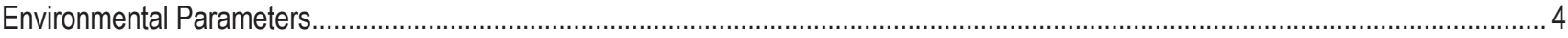

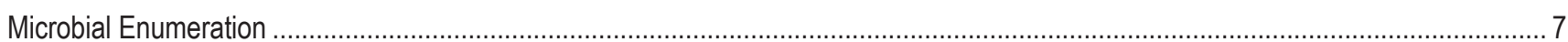

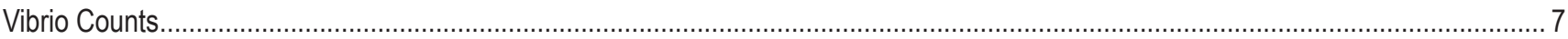

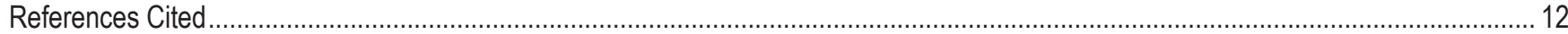

\section{Figures}

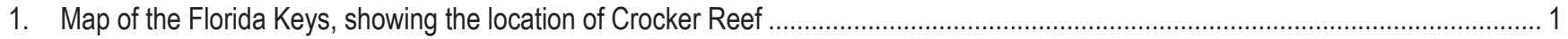

2. Seasonal water temperature and salinity values at the OCS and Coral sites, Crocker Reef, Florida Keys, 2014-2015................... 5

3. Seasonal water temperature and salinity values at the Seagrass and Rubble sites, Crocker Reef, Florida Keys, 2014-2015 ............ 5

4. Seasonal dissolved oxygen and pH values at the OCS and Coral sites, Crocker Reef, Florida Keys, 2014-2015........................... 6

5. Seasonal dissolved oxygen and pH values at the Seagrass and Rubble sites, Crocker Reef, Florida Keys, 2014-2015 .................... 6

6. Seasonal bacterial and viral counts at the OCS site, Crocker Reef, Florida Keys, 2014-2015 ..................................................... 8

7. Seasonal bacterial and viral counts at the Coral site, Crocker Reef, Florida Keys, 2014-2015 ............................................... 8

8. Seasonal bacterial and viral counts at the Seagrass site, Crocker Reef, Florida Keys, 2014-2015 ................................................ 9

9. Seasonal bacterial and viral direct counts at the Rubble site, Crocker Reef, Florida Keys, 2014-2015 ....................................... 9

\section{Tables}

1. Sites sampled for microbial and environmental parameters at Crocker Reef, Florida Keys, 2014-2015 ......................................... 2

2. Vibrio spp. plate counts, Crocker Reef, Florida Keys, 2014-2015 ................................................................................... 10 


\section{Conversion Factors}

International System of Units to Inch/Pound

\begin{tabular}{|c|c|c|}
\hline Multiply & By & To obtain \\
\hline \multicolumn{3}{|c|}{ Length } \\
\hline centimeter $(\mathrm{cm})$ & 0.3937 & inch (in.) \\
\hline meter $(\mathrm{m})$ & 3.281 & foot $(\mathrm{ft})$ \\
\hline \multicolumn{3}{|c|}{ Volume } \\
\hline liter $(\mathrm{L})$ & 1.0567 & quart (qt) \\
\hline \multicolumn{3}{|c|}{ Inch/Pound to International System of Units } \\
\hline Multiply & By & To obtain \\
\hline \multicolumn{3}{|c|}{ Length } \\
\hline inch (in.) & 2.54 & centimeter $(\mathrm{cm})$ \\
\hline inch (in.) & 25.4 & millimeter (mm) \\
\hline foot $(\mathrm{ft})$ & 0.3048 & meter $(\mathrm{m})$ \\
\hline mile, nautical (nmi) & 1.852 & kilometer $(\mathrm{km})$ \\
\hline
\end{tabular}

Temperature in degrees Celsius $\left({ }^{\circ} \mathrm{C}\right)$ may be converted to degrees Fahrenheit $\left({ }^{\circ} \mathrm{F}\right)$ as follows ${ }^{\circ} \mathrm{F}=\left(1.8 \times{ }^{\circ} \mathrm{C}\right)+32$.

\section{Datum}

Horizontal coordinate information is referenced to the North American Datum of 1983 (NAD 83).

\section{Abbreviations}

$\begin{array}{ll}\text { BDL } & \text { Below Detection Limit } \\ \text { CCA } & \text { Crustose Coralline Algae } \\ \text { CFU } & \text { Colony-Forming Units } \\ \text { CREST } & \text { Coral Reef Ecosystem Studies } \\ \text { DO } & \text { Dissolved Oxygen } \\ \text { ND } & \text { Not Determined } \\ \text { OCS } & \text { Ocean Carbon System } \\ \text { TCBS } & \text { Thiosulfate-Citrate-Bile Salts-Sucrose } \\ \text { TE } & \text { Tris-EDTA } \\ \text { TNTC } & \text { Too Numerous To Count } \\ \text { USGS } & \text { U.S. Geological Survey }\end{array}$

\section{Acknowledgments}

The authors gratefully acknowledge the assistance and support of Captain Joe Bailey and the crew of the M/V Playmate in obtaining these measurements. Molly R. McLaughlin of the U.S. Geological Survey and Zachary J. Gregg of the University of Tampa are thanked for their assistance in the field. 


\title{
Seasonal Microbial and Environmental Parameters at Crocker Reef, Florida Keys, 2014-2015
}

\author{
By Christina A. Kellogg, ${ }^{1}$ Kimberly K. Yates, ${ }^{1}$ Stephanie N. Lawler, ${ }^{2}$ Christopher S. Moore,${ }^{3}$ and Nathan A. Smiley ${ }^{1}$
}

\section{Introduction}

Crocker Reef, located on the outer reef tract of the Florida Keys (fig. 1), was the site of an integrated "reefscape characterization" effort focused on calcification and related biogeochemical processes as part of the U.S. Geological Survey (USGS) Coral Reef Ecosystem STudies (CREST) project. It is characterized as a senile or dead reef, with only scattered stony coral colonies and areas of sand and rubble. It was chosen as an end-member for later comparison to sites with a healthy, growing reef framework. The CREST reefscape characterization included two intensive seasonal sampling trips to capture summer (July 8-17, 2014) and winter (January 29-February 5, 2015) conditions. This report presents water column microbial and environmental data collected for use as metadata in future publications examining reef metabolic processes via metagenomes derived from water samples and fine-scale temporal and spatial carbonate chemistry measurements.

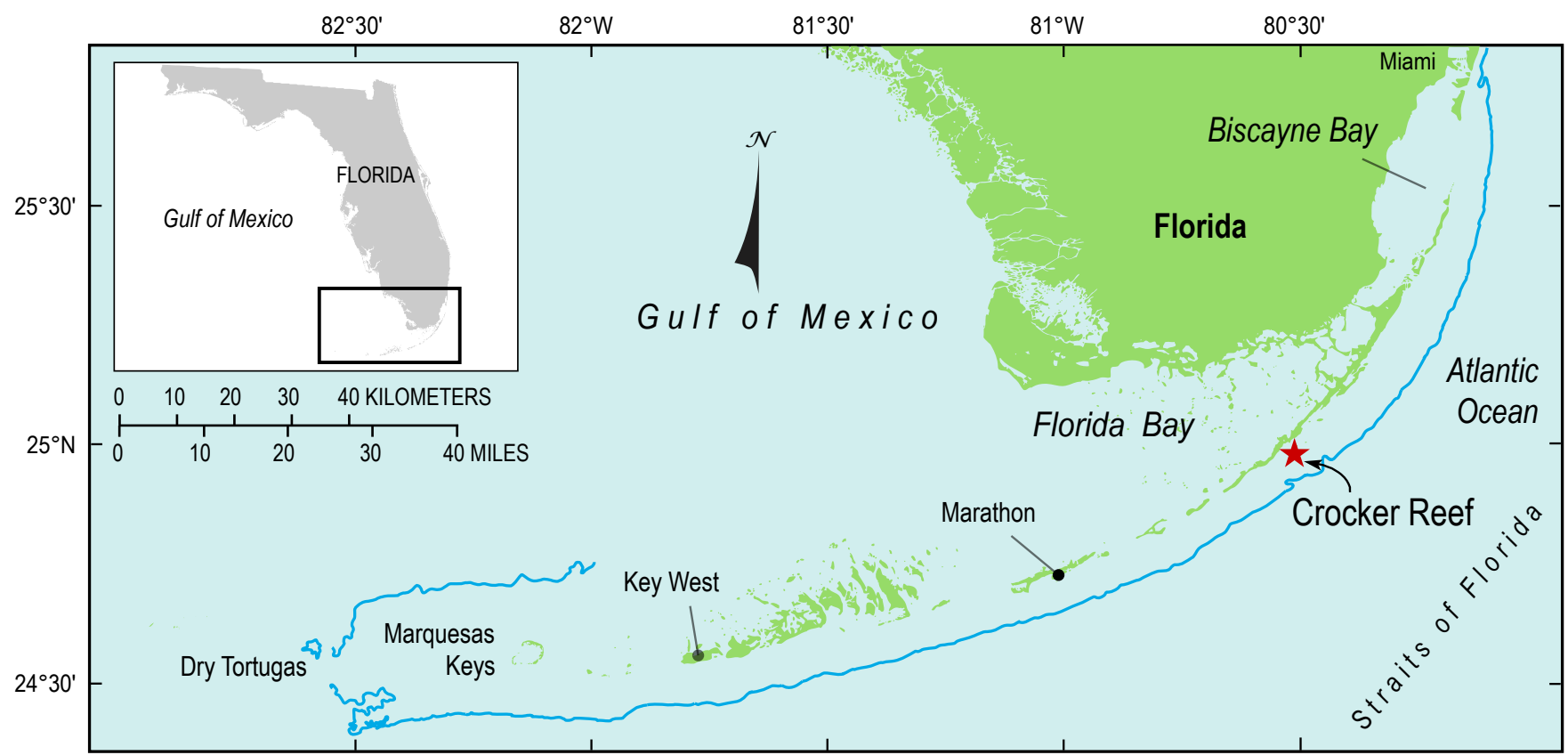

Figure 1. Map of the Florida Keys, showing the location of Crocker Reef.

${ }^{1}$ U.S. Geological Survey

${ }^{2}$ University of South Florida

${ }^{3}$ Cherokee Nation Technical Solutions, contractor to the U.S. Geological Survey 
Microbial measurements included enumeration of total bacteria, enumeration of virus-like particles, and plate counts of Vibrio spp. colony-forming units (CFU). These measurements were intended to give a sense of any seasonal changes in the total microbial load and to provide an indication of water quality. Additional environmental parameters measured included water temperature, salinity, dissolved oxygen, and $\mathrm{pH}$. Four sites (table 1) were intensively sampled for periods of approximately 48 hours during summer (July 2014) and winter (January-February 2015), during which water samples were collected every 4 hours for analysis, except when prevented by weather conditions.

Table 1. Sites sampled for microbial and environmental parameters at Crocker Reef, Florida Keys, 2014-2015.

[ , approximately; OCS, Ocean Carbon System; m, meters; ft, feet]

\begin{tabular}{|c|c|c|c|}
\hline Site name & $\begin{array}{l}\text { Latitude/Longitude } \\
\text { (in decimal degrees) }\end{array}$ & Water depth ${ }^{1}$ & Description \\
\hline $\mathrm{OCS}$ & $\begin{array}{l}24.90913 \mathrm{~N} \\
80.52644 \mathrm{~W}\end{array}$ & $\begin{array}{l}3.7 \text { meters } \\
(\sim 12 \text { feet })\end{array}$ & $\begin{array}{l}\text { Deployment site for the OCS instrumentation } \\
\text { package; sandy patch next to hardbottom. }\end{array}$ \\
\hline Coral & $\begin{array}{l}24.90897 \mathrm{~N} \\
80.52658 \mathrm{~W}\end{array}$ & $\begin{array}{l}3.7 \text { meters } \\
(\sim 12 \text { feet })\end{array}$ & $\begin{array}{l}\text { Hardbottom next to OCS site, featuring gorgo- } \\
\text { nians and scattered small scleractinian coral } \\
\text { colonies. }\end{array}$ \\
\hline Seagrass & $\begin{array}{l}24.91082 \mathrm{~N} \\
80.52775 \mathrm{~W}\end{array}$ & $\begin{array}{l}4.3 \text { meters } \\
(\sim 14 \text { feet })\end{array}$ & $\begin{array}{l}\text { Seagrass bed of intermediate density, featuring } \\
\text { Thalassia and Syringodium species. }\end{array}$ \\
\hline Rubble & $\begin{array}{l}24.91083 \mathrm{~N} \\
80.52758 \mathrm{~W}\end{array}$ & $\begin{array}{l}4.3 \text { meters } \\
(\sim 14 \text { feet })\end{array}$ & $\begin{array}{l}\text { Coarse coral rubble bed near seagrass; crustose } \\
\text { coralline algae on the underside of the rubble; } \\
\text { underlying bottom is sand. }\end{array}$ \\
\hline
\end{tabular}

${ }^{1}$ Water depth is approximate because it is shallow enough to be tidally influenced.

\section{Methods}

The Ocean Carbon System (OCS) and Coral sites are 22 meters (m) apart and were sampled concurrently while the sampling platform vessel remained anchored in a single location. The Seagrass and Rubble sites are $17 \mathrm{~m}$ apart and were also sampled concurrently from a single vessel location. The distance between the two pairs of sites is roughly $230 \mathrm{~m}$. The sites were chosen based on their differing benthic habitats (table 1) to characterize Crocker Reef. Seawater was collected at each site by using a peristaltic pump to draw water through tubing that was secured near the seafloor on either the OCS instrument package (at the OCS site) or on concrete blocks (at the other three sites), such that the intake was approximately 20 centimeters ( 8 inches) above the benthic substrate. During winter, a mesh prescreen was used to limit uptake of large suspended particulates that might clog the tubing, and during both seasons, a 0.45 -micrometer $(\mu \mathrm{m})$ prefilter was used to remove particulates that could affect water chemistry. Collection occurred every 4 hours $(n=13)$ for a period of 48 hours per site, unless interrupted by poor weather conditions. Specifically, the Seagrass and Rubble sites are missing data from July 13, 2014, at the 03:30 time point and were only sampled for 36 hours during the winter because the ship was unable to maintain position onsite. Samples were processed within 20 minutes of collection. 


\section{Environmental Parameters}

Temperature $\left( \pm 0.2\right.$ degrees Celsius $\left.\left[{ }^{\circ} \mathrm{C}\right]\right)$, salinity $( \pm 1.0$ percent of reading or 0.1 parts per thousand, whichever is greater), and dissolved oxygen $\left( \pm 0.1\right.$ milligrams per liter $\left.\left[\mathrm{mg} / \mathrm{L}^{-1}\right]\right)$ were measured using a YSI multimeter. Salinity was calculated within the multimeter based on conductivity ( \pm 1.0 percent of reading or 0.001 microsiemens per centimeter $[\mu \mathrm{S} / \mathrm{cm}]$, whichever is greater) and temperature measurements. The YSI multimeter was calibrated using $50,000 \mu \mathrm{S} / \mathrm{cm} \pm 1$ percent at $25^{\circ} \mathrm{C}$ conductivity standards from YSI. This calibration was done at the beginning of sampling at each study site and when batteries were changed in the unit. Samples were analyzed for total $\mathrm{pH}\left(\mathrm{pH}_{\mathrm{T}} ; \pm 0.005\right)$ using an Ocean Optics spectrophotometer and thymol blue indicator dye (Zhang and Byrne, 1996). Tidal information was obtained from the National Oceanic and Atmospheric Administration's Tides and Currents Web site, using the data from Snake Creek, Highway 1 bridge, Windley Key, FL (Station ID: 8723787 (National Oceanic and Atmospheric Administration, 2015).

\section{Microbial Enumeration}

Two cryovials were each filled with 4 milliliters $(\mathrm{mL})$ of seawater for each time point at each location. These samples were immediately flash-frozen in liquid nitrogen (Wen and others, 2004) and stored frozen in a dewar until transferred to $\mathrm{a}-80-^{\circ} \mathrm{C}$ freezer upon return to the laboratory. Bacterial and virus-like particles were counted in these samples by flow cytometry using a BD FACSCalibur ${ }^{\mathrm{TM}}$ flow cytometer (Brussaard, 2009). Cleanliness and consistency of the machine were maintained by completing routine weekly cleanings, and flow rates were calibrated at the beginning and end of each day. Before processing, water samples were removed from the $-80-^{\circ} \mathrm{C}$ freezer, thawed, and fixed in 25 -percent flow-grade glutaraldehyde for 15 minutes at $4{ }^{\circ} \mathrm{C}$. Working stock solutions of Tris-EDTA (TE) buffer, SYBR-Green nucleic acid stain, and Fluoresbrite plain $0.75-\mu \mathrm{m}$ microspheres were prepared daily for use as external and internal controls (Brussaard, 2009). Samples were prepared for enumeration of viruslike particles by using 880 microliters $(\mu \mathrm{L})$ of TE buffer, $10 \mu \mathrm{L}$ of SYBR-Green, 10- $\mu \mathrm{L}$ microspheres, and $100 \mu \mathrm{L}$ of water sample. The appropriate dilution for sample counting was determined by preparing several samples from each site as serial dilutions from 1:10 to 1:10,000. The majority of samples were used at the 1:10 dilution. Because bacterial abundance was lower than viral abundance, samples were prepared using $480 \mu \mathrm{L}$ of TE buffer, $10 \mu \mathrm{L}$ of SYBR-Green, 10- $\mu \mathrm{L}$ microspheres, and $500 \mu \mathrm{L}$ of water sample. Mixtures were incubated at $80^{\circ} \mathrm{C}$ for 10 minutes in the dark then cooled for 5 minutes before further analysis. From each duplicate water sample taken per time point (true replicates), 3 counts of 2 minutes each were done. Replicate samples were run on different days to compensate for any variation in the machine's performance; therefore, a total of 6 counts ( 2 replicates $\times 3$ counts) were averaged to produce each bacterial or viral count reported. A threshold of 200-1,000 events per second was used for the viral counts; however, many of the bacterial samples had less than 200 events per second in spite of the higher volume of sample enumerated.

\section{Vibrio Counts}

Separate water samples were collected in sterile 50-mL tubes for culture-based enumeration. Plate counts to enumerate bacteria belonging to the genus Vibrio were conducted while in the field by using thiosulfate-citrate-bile salts-sucrose (TCBS) agar medium (Kobayashi and others, 1963). Petri dishes containing the selective medium were prepared in the laboratory before the trip and brought into the field in a cooler. Water samples for each time point were plated in triplicate onto TCBS agar plates by 
aliquoting $100 \mu \mathrm{L}$ per plate and spreading the sample evenly with an ethanol-sterilized glass rod bent into an L-shape. Plates were incubated for 24 hours at $30{ }^{\circ} \mathrm{C}$, and then bacterial colonies that grew on the agar were counted using a hand tally. Counts were averaged across the three replicates and then multiplied by 10 to generate colony-forming units per milliliter $(\mathrm{CFU} / \mathrm{mL})$; therefore, the limit of detection for this assay was $3.3 \mathrm{CFU} / \mathrm{mL}$. No visible growth on any of the replicate plates was recorded as below detection limit (BDL). Plates that had more than 500 colonies were recorded as "too numerous to count" (TNTC).

\section{Results and Discussion}

Microbial and environmental data were collected in unison at the four sites listed in table 1. Collections were made every 4 hours over a 36-48-hour period. The data described in this report can be accessed online in a spreadsheet from the USGS Data Release titled "Microbial and environmental dataset from Crocker Reef, Florida Keys, 2014-2015” (http://dx.doi.org/10.5066/F74Q7S25).

\section{Environmental Parameters}

Because the OCS and Coral sites have similar profiles (due to their proximity to each other), and likewise for the Seagrass and Rubble sites, the environmental parameters are graphed per pair of sites (figs. 2-5). The summer temperature range across all sites was $29.0-31.9^{\circ} \mathrm{C}$, with $\mathrm{OCS} / \mathrm{Coral}$ being slightly warmer than Seagrass/Rubble (figs. 2-3). The winter temperature range was $22.2-25.4{ }^{\circ} \mathrm{C}$, again with OCS/Coral being slightly warmer than Seagrass/Rubble. All sites showed a temperature peak in the late afternoon (typically 15:30) during both seasons.

Salinity at the Seagrass/Rubble sites ranged from 36.30 to 36.68 all year, with no obvious seasonal component (fig. 3). OCS/Coral sites had a saline pulse in the summer with salinities up to 37.57 (fig. 2), but otherwise salinity measurements were similar in range to those at the Seagrass/Rubble sites. This saline pulse at the OCS/Coral sites is not reflected in any of the microbial parameters.

The dissolved oxygen (DO) profiles at the OCS/Coral sites were similar to each other during both seasons (fig. 4). The summer profiles exhibited faint minimums in the early morning (07:30) and small peaks in the late afternoon (15:30-19:30). The OCS/Coral sites' winter DO values were consistently higher than the summer values. However, at the Seagrass and Rubble sites, the DO does not follow a similar pattern (fig. 5). While the Seagrass winter DO is higher than the summer DO (as seen at OCS/Coral), the Rubble summer and winter DO values are similar in scale and tend to have opposite highs and lows. Seagrass and Rubble summer DO values are similar over all but one of the time points measured, but the two sites have divergent winter DO profiles.

All pH values were between 8.022 and 8.120 (figs. 4 and 5). As with other environmental parameters, the OCS and Coral summer $\mathrm{pH}$ values tracked each other very closely and followed the same pattern, with the $\mathrm{pH}$ values at the OCS site being slightly higher than the $\mathrm{pH}$ values at the Coral site (fig. 4). The two dips in the OCS/Coral summer $\mathrm{pH}$ data both occurred in the morning (07:30). The winter values for these sites were higher than the summer values except at a few points, but the $\mathrm{pH}$ values at the two sites did not co-vary as in summer, and in fact, sometimes the trends are opposite. The Seagrass/ Rubble $\mathrm{pH}$ data were not as tightly coupled at the two sites as other environmental parameters (fig. 5). As seen at the OCS/Coral sites, winter $\mathrm{pH}$ values were higher than summer $\mathrm{pH}$ values at the Seagrass/ Rubble sites. In the winter, $\mathrm{pH}$ values at the Rubble site were higher than those at the Seagrass site, but the opposite is true in the summer. The lowest $\mathrm{pH}$ value of the dataset occurred at the Seagrass site during the summer, and was not echoed in the $\mathrm{pH}$ value at the Rubble site from the same time point. 


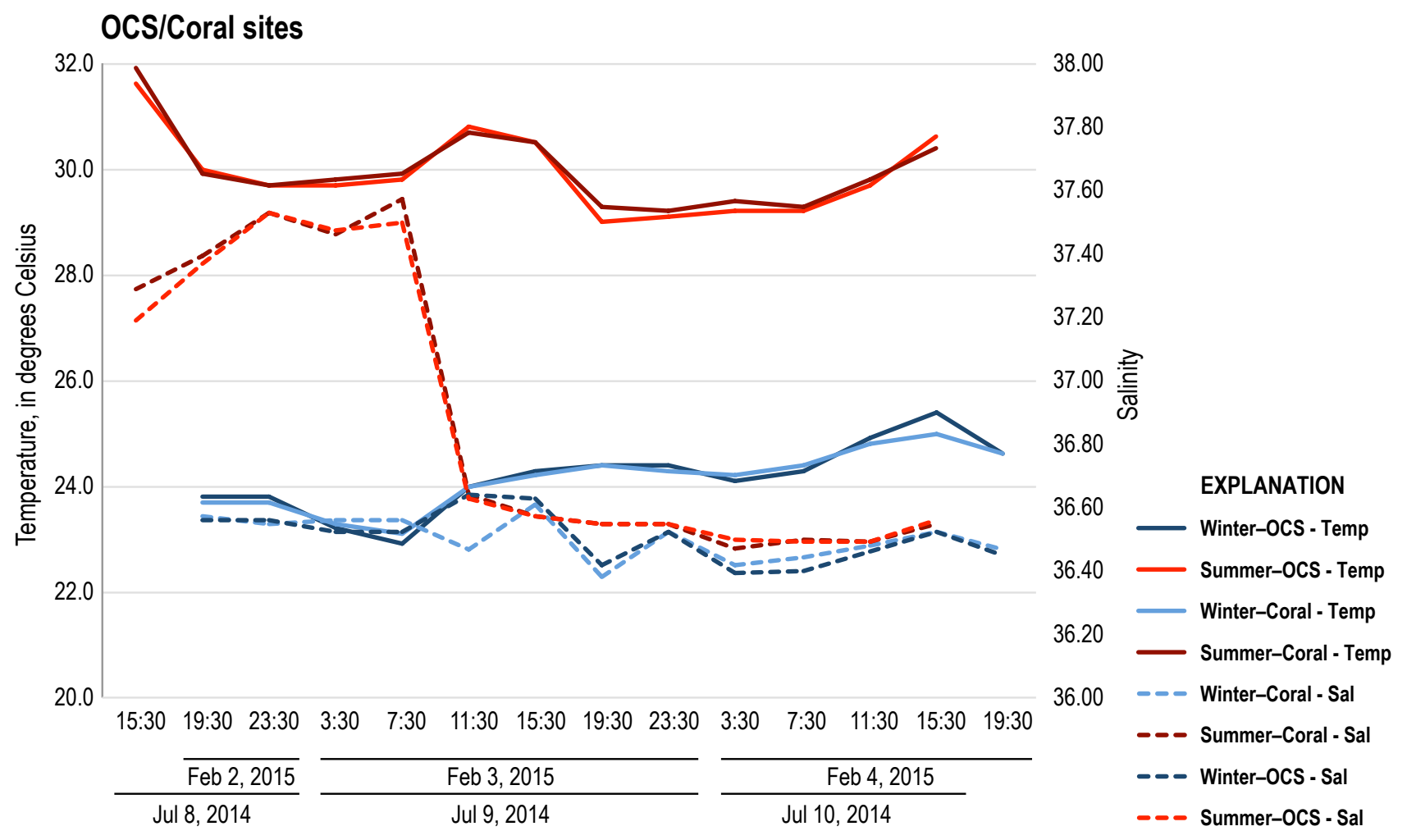

Figure 2. Seasonal water temperature and salinity values at the OCS and Coral sites, Crocker Reef, Florida Keys, 2014-2015.

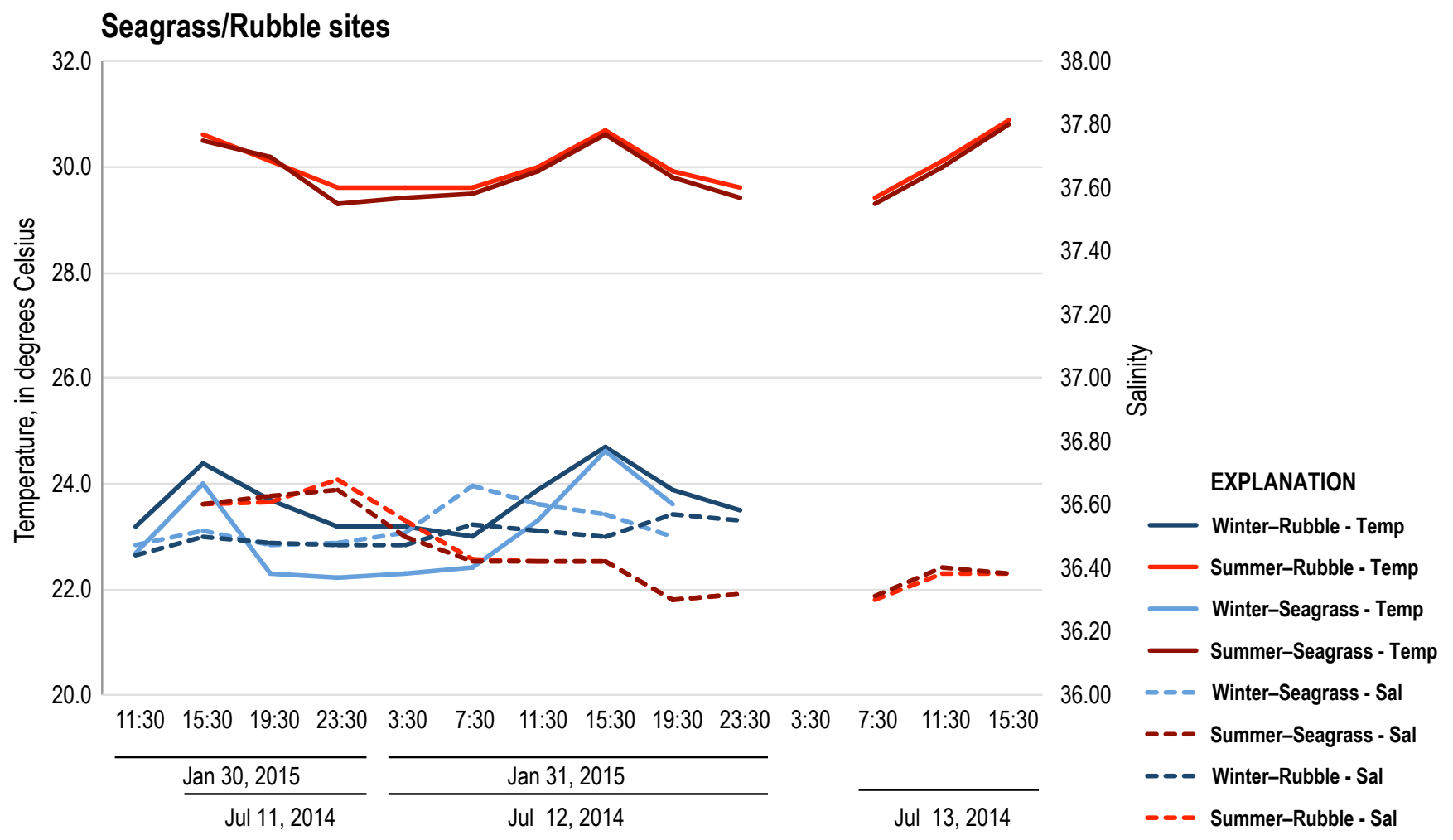

Figure 3. Seasonal water temperature and salinity values at the Seagrass and Rubble sites, Crocker Reef, Florida Keys, 2014-2015. 


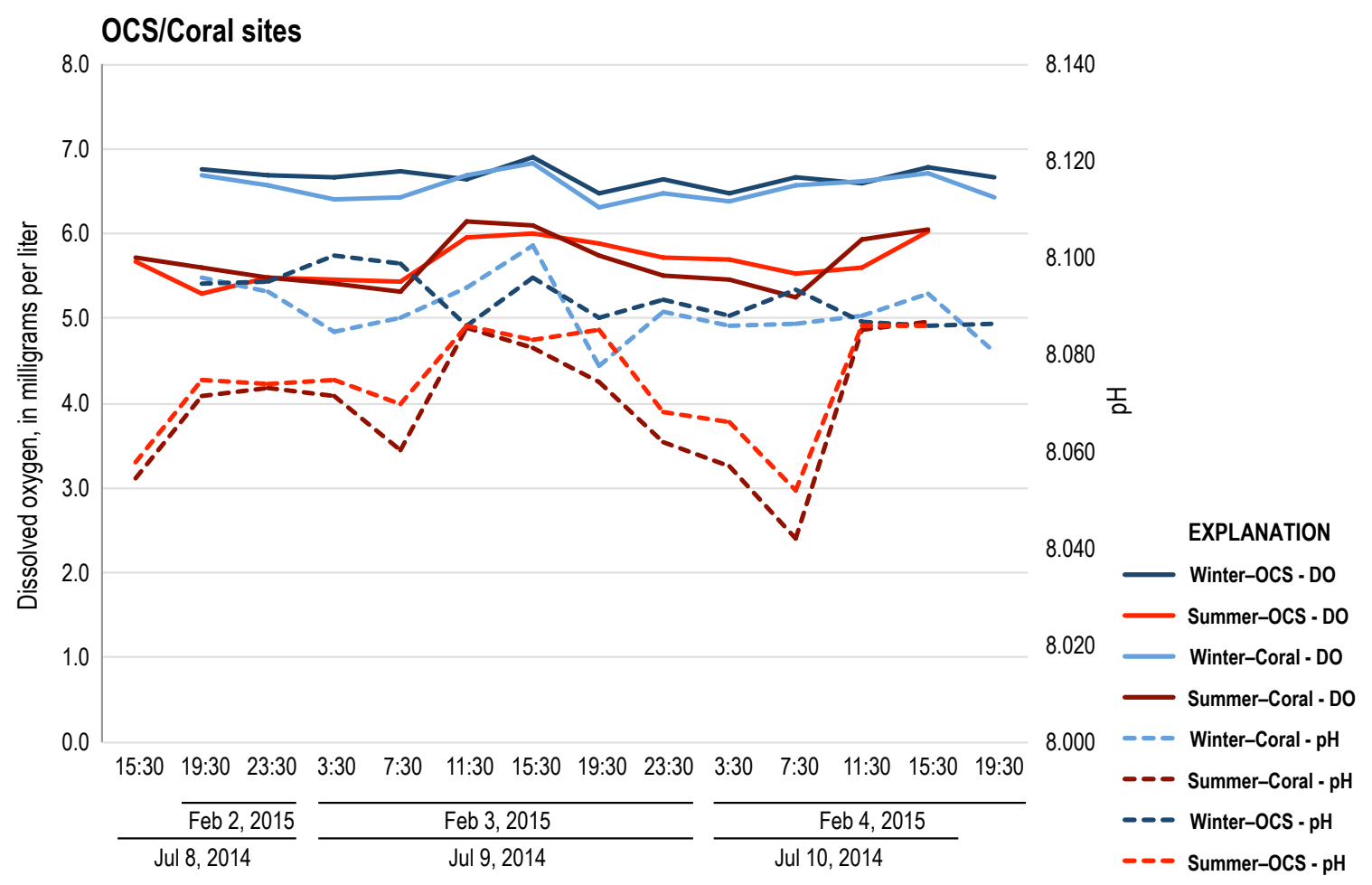

Figure 4. Seasonal dissolved oxygen and pH values at the OCS and Coral sites, Crocker Reef, Florida Keys, 2014-2015.

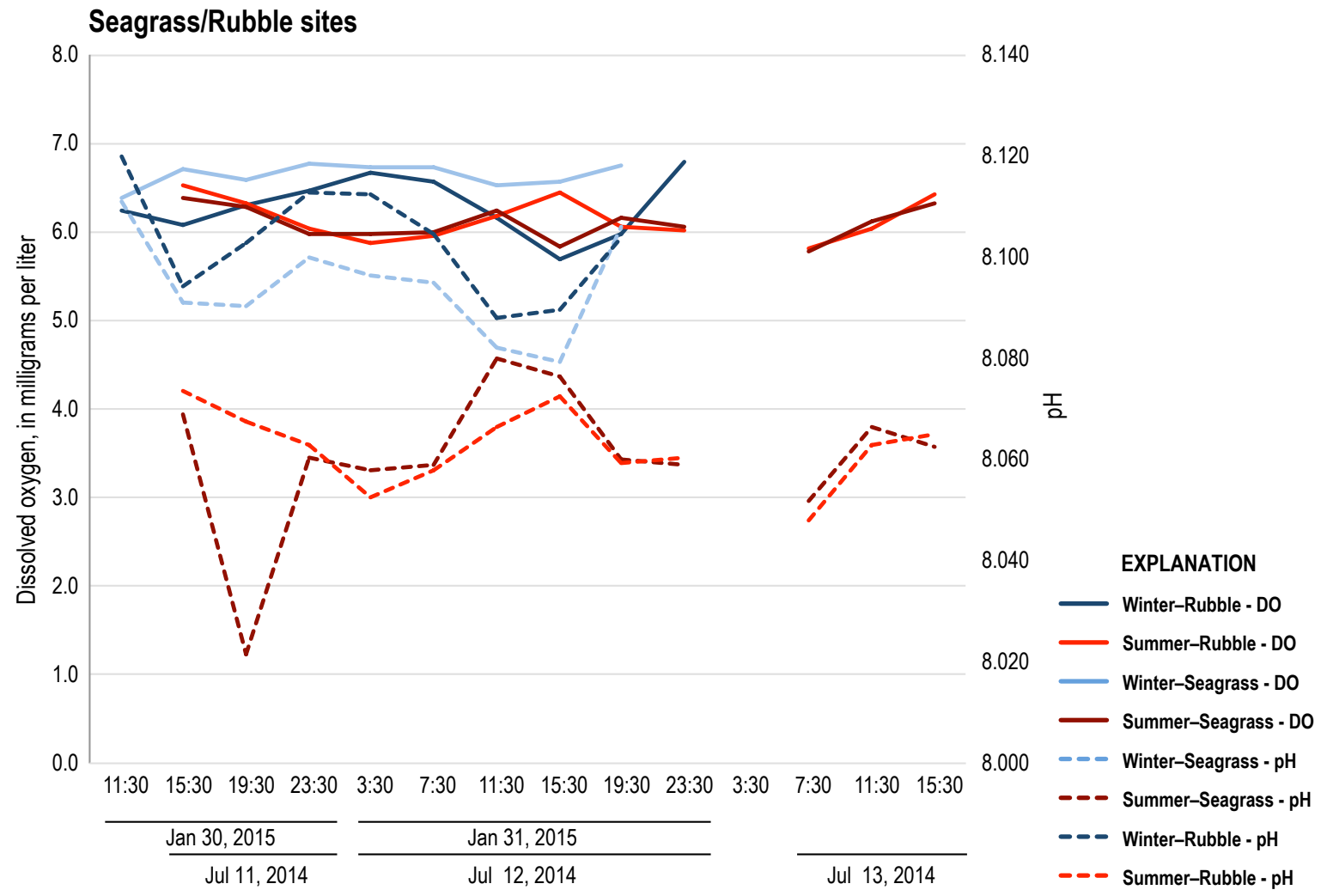

Figure 5. Seasonal dissolved oxygen and pH values at the Seagrass and Rubble sites, Crocker Reef, Florida Keys, 2014-2015. 


\section{Microbial Enumeration}

All viral-like particle counts were in the range of $\mathrm{E}+06$ to $\mathrm{E}+07$ (also written $10^{6}-10^{7}$ ) particles/ $\mathrm{mL}$ during the winter and summer; however, the winter viral counts were consistently higher than summer viral counts at all sites (figs. 6-9). In winter, the viral counts appear to track tides, with peaks corresponding to high tides and troughs corresponding to low tides, particularly at the Seagrass and Rubble sites. This tidal association was weaker, but still present, in the summer. Bacterial counts were relatively consistent all year at $10^{5}$ cells $/ \mathrm{mL}$ and showed no obvious pattern based on season or time of collection. The bacterial and viral numbers are consistent with previous measurements made in Key Largo (Paul and others, 1993), however, the inverse correlation between viral counts and salinity that those authors reported was not observed during this study.

\section{Vibrio Counts}

During the first field trip (July 2014), many of the TCBS agar plates were damaged in transit to the field; therefore, no samples were tested for vibrio counts at the Coral site, and samples were not tested for all time points for the Seagrass and Rubble sites (ND; table 2). Also due to the limited number of plates available, only one sample volume $(100 \mu \mathrm{L})$ could be plated, which resulted in some plates being uncountable due to an excess of colonies (TNTC; table 2). During the winter trip (January-February 2015), no water samples were tested for vibrio counts at the Coral site because no summer data were available for comparison.

During the summer, the OCS site had concentrations of vibrios ranging from 10.0 to $390.0 \mathrm{CFU} /$ $\mathrm{mL}$, with the highest number occurring at 23:30 on July 9 during a falling tide. The Seagrass and Rubble sites had higher vibrio concentrations in the summer than those seen at the OCS site, ranging from $200 \mathrm{CFU} / \mathrm{mL}$ to TNTC (estimated to be greater than 5,000 CFU/mL). At the Seagrass site, the number of vibrios was higher during the day than at night, with the highest concentrations coinciding with the day's temperature peak (table 2; fig. 3). While the Seagrass and Rubble sites' summer environmental data are similar (figs. 3 and 5), the Rubble site had much higher vibrio counts for the same time period (table 2). Even though $\mathrm{pH}$ values differ a bit between the two sites during this time period, with the Rubble site having slightly lower $\mathrm{pH}$ values (fig. 5), it is likely that factors other than $\mathrm{pH}$ are controlling the vibrio counts. Nutrient differences between the two sites or some effect of the benthic cover, such as seagrass instead of crustose coralline algae (CCA) on the rubble, are possible factors not examined in this report. Vibrio spp. have been reported in association with seagrass sediments (Bagwell and others, 2002) and CCA (Webster and others, 2011), but only as minor members of the microbial communities.

The vibrio concentrations were much lower at all three sites tested (OCS, Seagrass, Rubble) during the winter than during the summer, ranging from 0 to $60 \mathrm{CFU} / \mathrm{mL}$. This is likely due to the lower water temperatures because water column vibrio counts are known to correlate with temperature (Kaneko and Colwell, 1973). Winter counts had no obvious patterns except possibly at the Rubble site, where the counts peaked in the late afternoon during one tidal cycle. 
$8.00 \mathrm{E}+05$

$2.00 \mathrm{E}+07$

$7.00 \mathrm{E}+05$

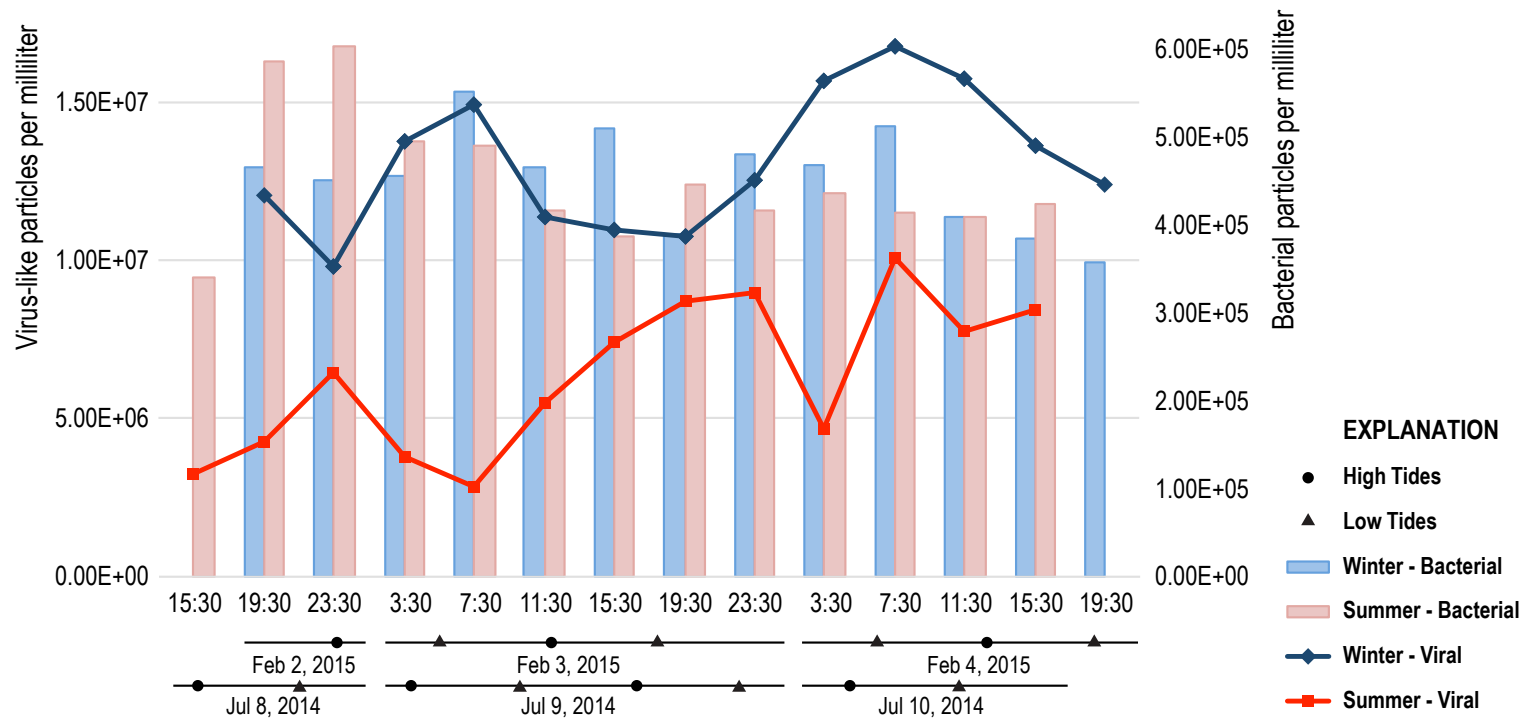

Figure 6. Seasonal bacterial and viral counts at the OCS site, Crocker Reef, Florida Keys, 2014-2015.

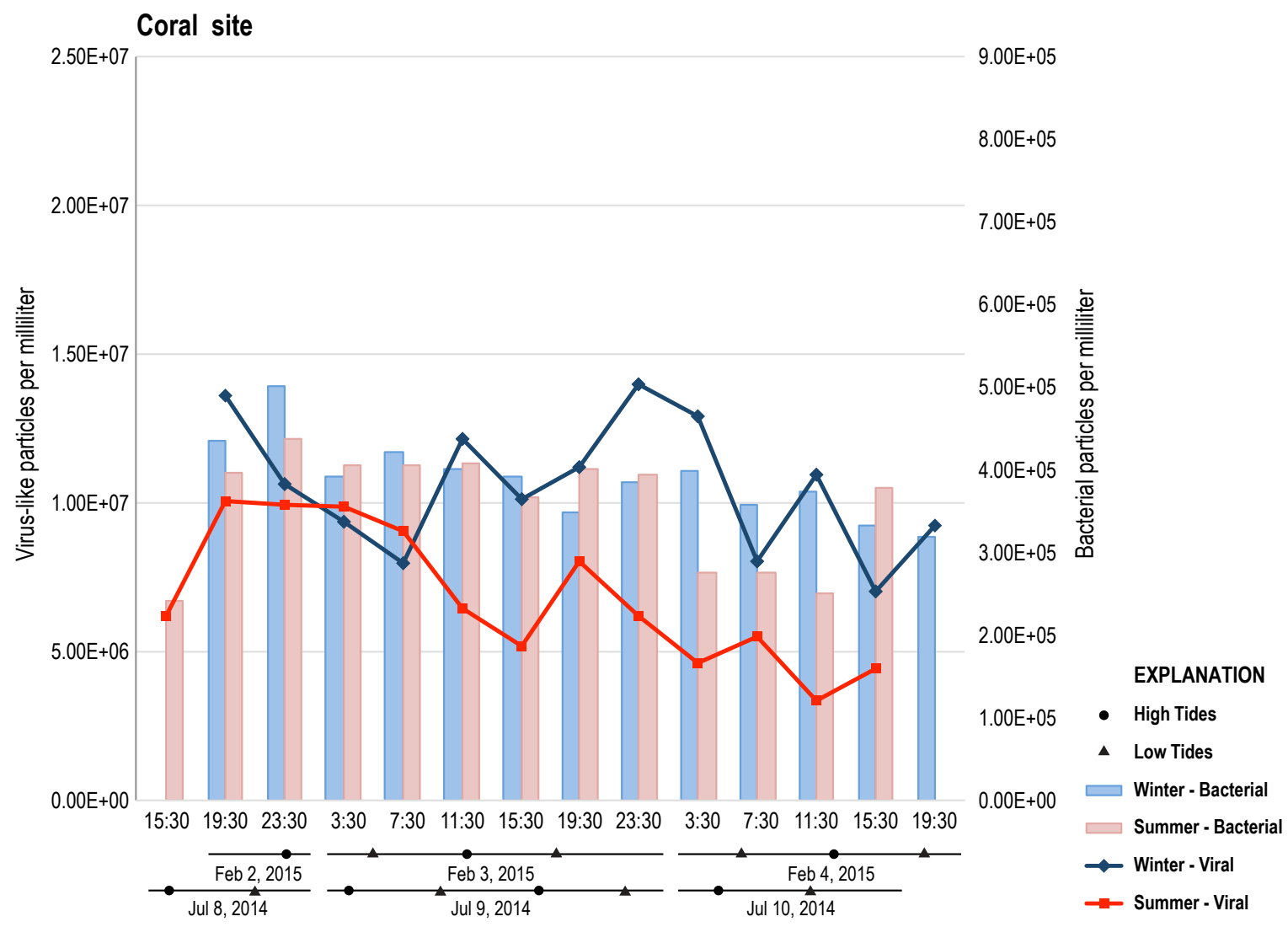

Figure 7. Seasonal bacterial and viral counts at the Coral site, Crocker Reef, Florida Keys, 2014-2015. 


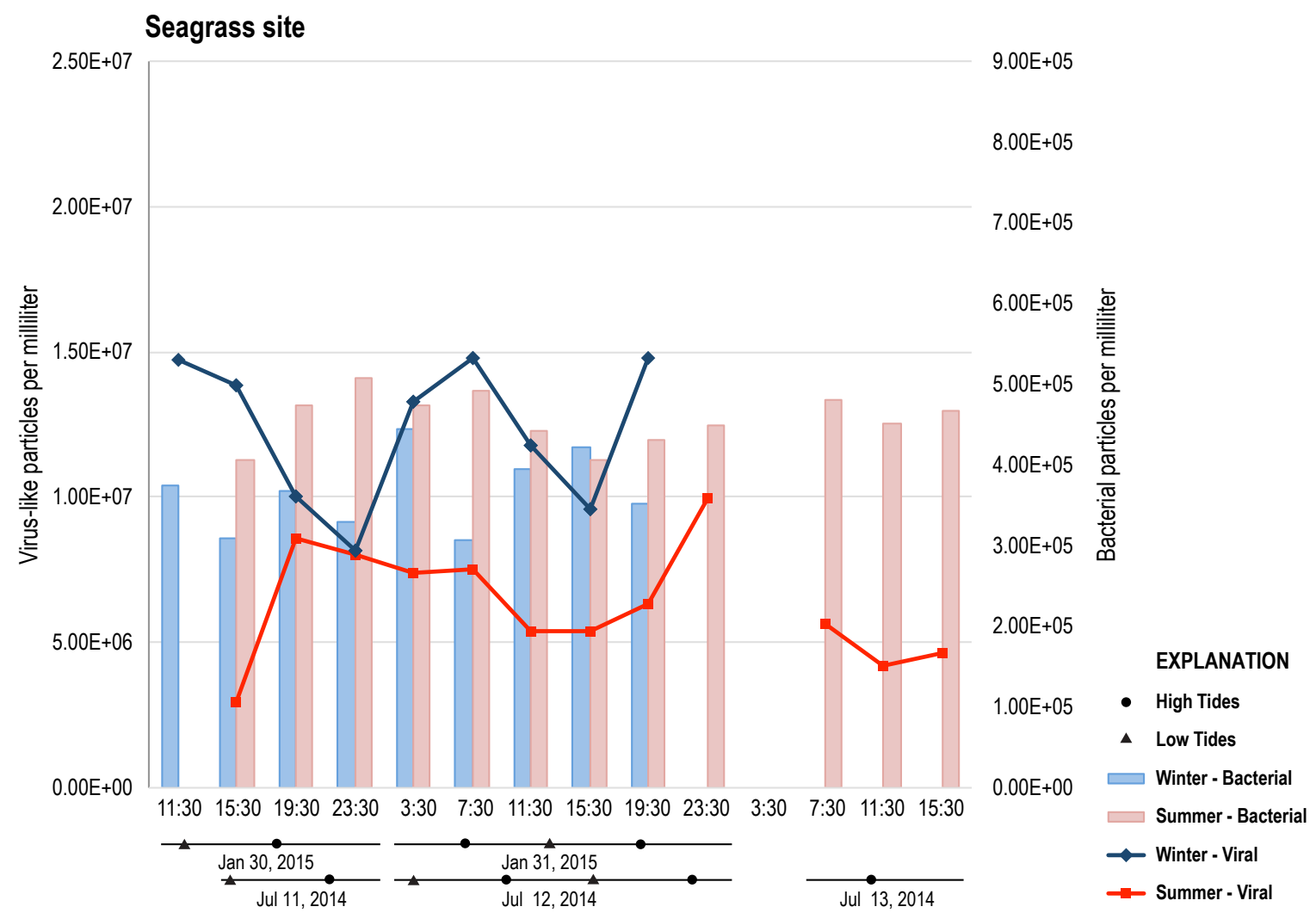

Figure 8. Seasonal bacterial and viral counts at the Seagrass site, Crocker Reef, Florida Keys, 2014-2015.

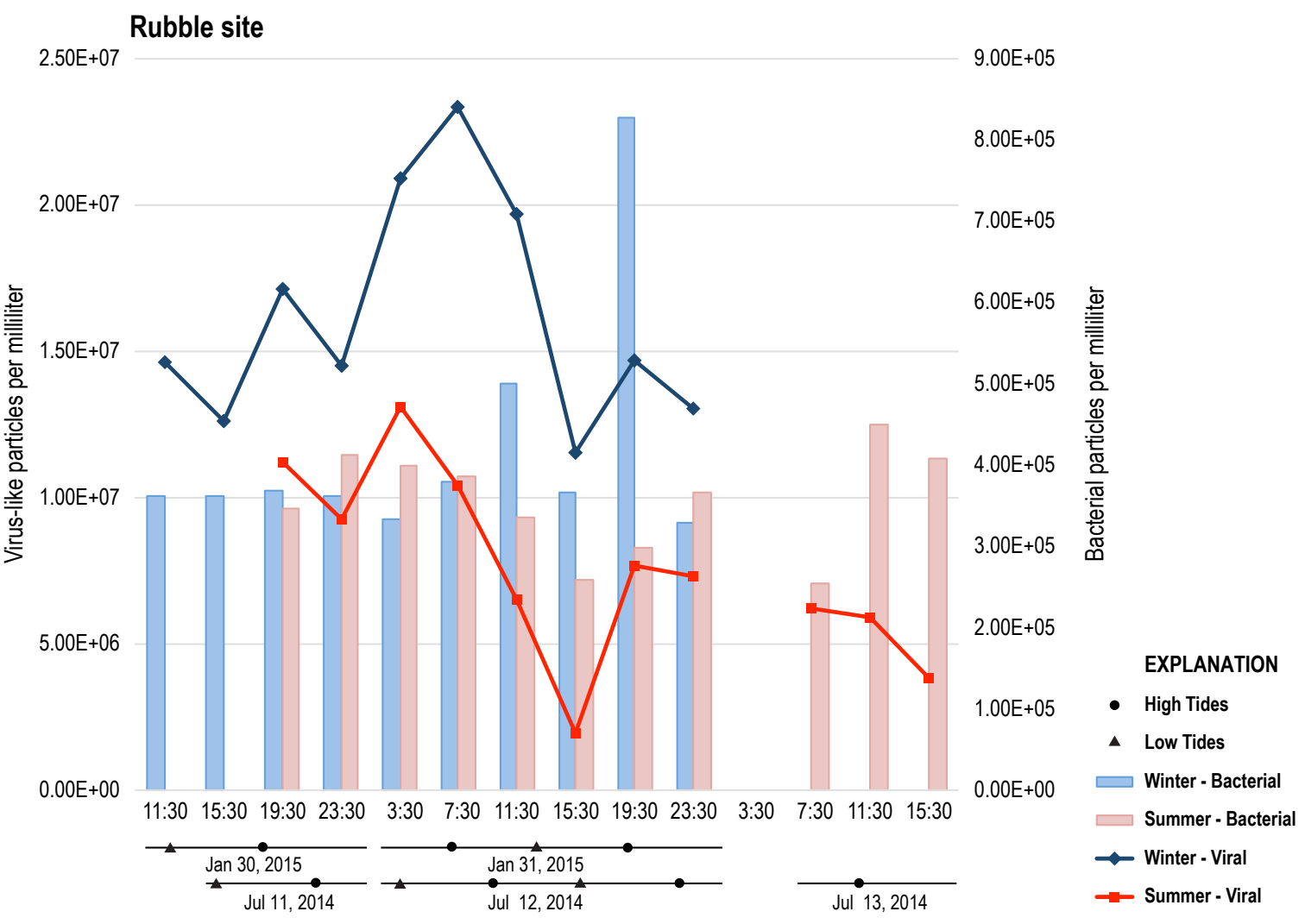

Figure 9. Seasonal bacterial and viral direct counts at the Rubble site, Crocker Reef, Florida Keys, 2014-2015. 
Table 2. Vibrio spp. plate counts, Crocker Reef, Florida Keys, 2014-2015.

$[\mathrm{CFU} / \mathrm{mL}$, colony-forming units per milliliter of seawater; BDL, below detection limit; ND, not determined; TNTC, too numerous to count; see table 1 for site information]

\begin{tabular}{|c|c|c|c|}
\hline Site-Season & Date & Time & Vibrio spp., CFU/mL \\
\hline OCS-Summer & 08-Jul-2014 & $15: 30$ & 16.7 \\
\hline OCS-Summer & 08-Jul-2014 & 19:30 & 23.3 \\
\hline OCS-Summer & 08-Jul-2014 & $23: 30$ & 43.3 \\
\hline OCS-Summer & 09-Jul-2014 & 03:30 & 33.3 \\
\hline OCS-Summer & 09-Jul-2014 & $07: 30$ & 53.3 \\
\hline OCS-Summer & 09-Jul-2014 & $11: 30$ & 36.7 \\
\hline OCS-Summer & 09-Jul-2014 & $15: 30$ & 53.3 \\
\hline OCS-Summer & 09-Jul-2014 & $19: 30$ & 80.0 \\
\hline OCS-Summer & 09-Jul-2014 & $23: 30$ & 390.0 \\
\hline OCS-Summer & 10-Jul-2014 & $03: 30$ & 26.7 \\
\hline OCS-Summer & 10-Jul-2014 & 07:30 & 70.0 \\
\hline OCS-Summer & 10-Jul-2014 & $11: 30$ & 10.0 \\
\hline OCS-Summer & 10-Jul-2014 & $15: 30$ & 23.3 \\
\hline OCS-Winter & 02-Feb-2015 & $19: 30$ & 3.3 \\
\hline OCS-Winter & 02-Feb-2015 & $23: 30$ & 10.0 \\
\hline OCS-Winter & 03-Feb-2015 & 03:30 & 6.7 \\
\hline OCS-Winter & 03-Feb-2015 & $07: 30$ & 20.0 \\
\hline OCS-Winter & 03-Feb-2015 & $11: 30$ & 6.7 \\
\hline OCS-Winter & 03-Feb-2015 & $15: 30$ & 13.3 \\
\hline OCS-Winter & 03-Feb-2015 & $19: 30$ & 30.0 \\
\hline OCS-Winter & 03-Feb-2015 & $23: 30$ & 6.7 \\
\hline OCS-Winter & 04-Feb-2015 & 03:30 & 3.3 \\
\hline OCS-Winter & 04-Feb-2015 & $07: 30$ & 20.0 \\
\hline OCS-Winter & 04-Feb-2015 & $11: 30$ & 26.7 \\
\hline OCS-Winter & 04-Feb-2015 & $15: 30$ & 6.7 \\
\hline OCS-Winter & 04-Feb-2015 & 19:30 & 13.3 \\
\hline Seagrass-Summer & 11-Jul-2014 & $15: 30$ & ND \\
\hline Seagrass-Summer & 11-Jul-2014 & 19:30 & ND \\
\hline Seagrass-Summer & 11-Jul-2014 & $23: 30$ & ND \\
\hline Seagrass-Summer & 12-Jul-2014 & 03:30 & 570.0 \\
\hline Seagrass-Summer & 12-Jul-2014 & $07: 30$ & 210.0 \\
\hline Seagrass-Summer & 12-Jul-2014 & $11: 30$ & 3060.0 \\
\hline Seagrass-Summer & 12-Jul-2014 & $15: 30$ & TNTC \\
\hline Seagrass-Summer & 12-Jul-2014 & $19: 30$ & 1816.7 \\
\hline
\end{tabular}


Table 2. Vibrio spp. plate counts, Crocker Reef, Florida Keys, 2014-2015.-Continued

[CFU/mL, colony-forming units per milliliter of seawater; BDL, below detection limit; ND, not determined; TNTC, too numerous to count; see table 1 for site information]

\begin{tabular}{|c|c|c|c|}
\hline Site-Season & Date & Time & Vibrio spp., CFU/mL \\
\hline Seagrass-Summer & 12-Jul-2014 & $23: 30$ & 413.3 \\
\hline Seagrass-Summer & 13-Jul-2014 & $07: 30$ & ND \\
\hline Seagrass-Summer & 13-Jul-2014 & $11: 30$ & ND \\
\hline Seagrass-Summer & 13-Jul-2014 & $15: 30$ & ND \\
\hline Seagrass-Winter & 30-Jan-2015 & $11: 30$ & BDL \\
\hline Seagrass-Winter & 30-Jan-2015 & $15: 30$ & BDL \\
\hline Seagrass-Winter & 30-Jan-2015 & $19: 30$ & 3.3 \\
\hline Seagrass-Winter & 30-Jan-2015 & $23: 30$ & BDL \\
\hline Seagrass-Winter & 31-Jan-2015 & $03: 30$ & BDL \\
\hline Seagrass-Winter & 31-Jan-2015 & $07: 30$ & 6.7 \\
\hline Seagrass-Winter & 31-Jan-2015 & $11: 30$ & 6.7 \\
\hline Seagrass-Winter & 31-Jan-2015 & $15: 30$ & 6.7 \\
\hline Seagrass-Winter & 31-Jan-2015 & $19: 30$ & 30.0 \\
\hline Rubble-Summer & 11-Jul-2014 & $19: 30$ & ND \\
\hline Rubble-Summer & 11-Jul-2014 & $23: 30$ & ND \\
\hline Rubble-Summer & 12-Jul-2014 & $03: 30$ & TNTC \\
\hline Rubble-Summer & 12-Jul-2014 & $07: 30$ & TNTC \\
\hline Rubble-Summer & 12-Jul-2014 & $11: 30$ & TNTC \\
\hline Rubble-Summer & 12-Jul-2014 & $15: 30$ & TNTC \\
\hline Rubble-Summer & 12-Jul-2014 & $19: 30$ & TNTC \\
\hline Rubble-Summer & 12-Jul-2014 & $23: 30$ & TNTC \\
\hline Rubble-Summer & 13-Jul-2014 & 03:30 & ND \\
\hline Rubble-Summer & 13-Jul-2014 & $11: 30$ & ND \\
\hline Rubble-Summer & 13-Jul-2014 & $15: 30$ & ND \\
\hline Rubble-Winter & 30-Jan-2015 & $11: 30$ & $\mathrm{BDL}$ \\
\hline Rubble-Winter & 30-Jan-2015 & $15: 30$ & $\mathrm{BDL}$ \\
\hline Rubble-Winter & 30-Jan-2015 & $19: 30$ & 6.7 \\
\hline Rubble-Winter & 30-Jan-2015 & $23: 30$ & 10.0 \\
\hline Rubble-Winter & 31-Jan-2015 & 03:30 & 3.3 \\
\hline Rubble-Winter & 31-Jan-2015 & $07: 30$ & 10.0 \\
\hline Rubble-Winter & 31-Jan-2015 & $11: 30$ & 10.0 \\
\hline Rubble-Winter & 31-Jan-2015 & $15: 30$ & 60.0 \\
\hline Rubble-Winter & 31-Jan-2015 & $19: 30$ & 76.6 \\
\hline Rubble-Winter & 31-Jan-2015 & $23: 30$ & 3.3 \\
\hline
\end{tabular}




\section{References Cited}

Bagwell, C.E., La Rocque, J.R., Smith, G.W., Polson, S.W., Friez, M.J., Longshore, J.W., and Lovell, C.R., 2002, Molecular diversity of diazotrophs in oligotrophic tropical seagrass bed communities: FEMS Microbiology Ecology, v. 39, p. 113-119.

Brussaard, C.P.D., 2009, Enumeration of bacteriophages using flow cytometry, in Clokie, M.R.J., and Kropinski, A.M., eds., Bacteriophages: Humana Press, p. 97-111.

Kaneko, T., and Colwell, R.R., 1973, Ecology of Vibrio parahaemolyticus in the Chesapeake Bay: Journal of Bacteriology, v. 113, p. 24-32.

Kobayashi, T., Enomoto, S., Sakazaki, R., and Kuwahara, S., 1963, A new selective isolation medium for pathogenic vibrios: TCBS-Agar: Japanese Journal of Bacteriology, v. 18, p. 391-397.

National Oceanic and Atmospheric Administration, 2015, Tides and Currents, Snake Creek, Hwy 1 bridge, Windley Key, FL StationID: 8723787, accessed August 18, 2015, at http://tidesandcurrents. noaa.gov/noaatidepredictions/NOAATidesFacade.jsp?Stationid $=8723787$.

Paul, J.H., Rose, J.B., Jiang, S.C., Kellogg, C.A., and Dickson, L., 1993, Distribution of viral abundance in the reef environment of Key Largo, Florida: Applied and Environmental Microbiology, v. 59, p. 718-724.

Webster, N.S., Soo, R., Cobb, R., and Negri, A.P., 2011, Elevated seawater temperature causes a microbial shift on crustose coralline algae with implications for the recruitment of coral larvae: The ISME Journal, v. 5, p. 759-770.

Wen, K., Ortmann, A.C., and Suttle, C.A., 2004, Accurate estimation of viral abundance by epifluorescence microscopy: Applied and Environmental Microbiology, v. 70, no. 7, p. 3862-3867.

Zhang, H., and Byrne, R.H., 1996, Spectrophotometric $\mathrm{pH}$ measurements of surface seawater at in-situ conditions: Absorbance and protonation behavior of thymol blue: Marine Chemistry, v. 52, p. 17-25. 
